\title{
CREAT AN APPLICATION IN EXCEL SPREADSHEET PROGRAM TO FORMULATE POULTRY RATIONS BY A TRAIL AND ERROR METHOD
}

Rafh Mohamed Tahir Khalel

Poult. Prod. Dept., Fac. of Agric. and forestry, Mosul Univ., Iraq Corresponding author: Rafh Mohamed Tahir Khalel; Email: raf3taher@yahoo.com

Received: $15 / 10 / 2017 \quad$ Accepted: $31 / 10 / 2017$

ABSTRACT: This study aims to creating an application in the widespread Excel spreadsheet program, using the common feed materials used in poultry rations include maize, wheat, barley, soybean meal, wheat bran, sunflower oil, protein concentrate, limestone, salt, diCalcium Phosphate, premix of vitamins and minerals, anti-coccidial, where the function property in Excel program, especially the sum - product function, can be used to create an application for formulating rations in a trial and error method until reaching the desired goal in terms of its nutrient content: (dry matter, crude protein, lysine, methionine, methionine and cysteine, calcium, available phosphorus, crude fiber, ether extract, linoleic acid, chlorine, sodium, arginine, phenylalanine, phenylalanine and tyrosine, threonine, tryptophan, leucine, Valine, histidine, glycine, glycine and Serine, as well as soluble carbohydrates, ash)\%, in addition to estimate the cost of the ration.

Keywords: Application creation - Excel - Poultry feed. 


\section{INTRODUCTION}

Feed is the most important factor in influencing production costs, representing more than $70 \%$ of the total costs. The ration is defined as the amount of feed given to the animal daily. The process of the formulation is a process of mixing a group of ingredients to provide the animal with the appropriate amounts of nutrients needs them at an age and with least costs (Afolayan and Afolayan, 2008) The animals' commercial rations can be formulated using a number of methods, including the Pearson square which has been widely used and its disadvantages are that only one nutrient can be balanced by two ingredients at a time, also can be formulated depending on linear programming which is widely used in the feed industry by computer programs, it depends on mixing a range of ingredients to obtain the required nutrient levels at the lowest possible cost. It requires extensive knowledge from the animal nutritionist, who must take into account the animal's nutritional needs and its ability to digest and metabolize (Chakeredza et al., 2008; Roush, 1994). The other way is to use linear programming using the manual Simplex method. It needs long calculations and has been used for the first time in balancing animal diets at the lowest possible cost by Waugh in the early 1950s (Vandehaar and Black, 1991). There is a method of manual trial and error which it takes a long time to balance the diet, and to balance all the nutrients and not take into account the cost of ration, it is one of the most widely used by university students and researchers in Iraq, but takes a lot of time in the process of multiplication and summation and the repetition of the attempt to trying to reach the formula that provides the required feed requirements and sometimes characterized by extreme difficulty, especially when using the decimal parts in the proportions of feed materials. The method of trial and error depends on the creation of a worksheet that includes fields to enter the names of the available feed materials and their chemical composition of the various nutrients and a field to enter the proportions of feed materials where the ratios of feed materials are assumed and find the nutrients they provide, then modify these ratios and repeat of multiplication and collection until reaching the goal (Yassin and Abdel-Abbas, 2010). Excel is one of the most widely distributed programs in the Office suite and works on computers under Windows (Pesti and Seila, 1999). It contains a wide range of functions that can be relied upon to shorten the time required for multiplication and summation, the most important of which is the Sum-product function.

The purpose of this research is to create an application in Excel using functions to use it to formulate rations of poultry in a trial and error method, for example, broilers. 
Application creation - Excel - Poultry feed.

\section{MATERIALS AND METHODS}

The application consists of an Excel spreadsheet (as in Fig. 1) consisting of four working sheets. In the main sheet, the first column $\mathrm{C}$ lists the names of the feedstuffs used to formulate the ration (Maize, wheat, barley, wheat bran, soybeans meal, protein concentrate, lime, salt, dicalcium phosphate, vitamins and mineral premix, anticoccidial, in column (D), the ratio of feedstuffs as decimals and in column (E) the proportions of feedstuffs as a percentage of the diet, and in column $(\mathrm{F})$ the cost of each feedstuff (ID / kg), and the D16, E16 and F16 cells represent the total of the components of the feedstuffs as a decimal, percentage, and cost of the total diet respectively. In cells I4 to K16, the following percentages are: dry matter\%, metabolizable energy (kcal / kg), crude protein \%, lysine $\%$, methionine $\%$, methionine and cysteine $\%$, calcium $\%$, available phosphorus $\%$, crude fiber $\%$, ether extract $\%$, linoleic acid $\%$, chlorine $\%, \quad$ sodium $\%$ arginine $\%$, phenylalanine $\%$, phenylalanine and tyrosin $\%$, threonine \%, tryptophan $\%$, leucine $\%$, isolucine $\%$, glycine $\%$, glycine and serine $\%$, soluble carbohydrates $\%$, ash\%, respectively in total diet. The values of the cost of feedstuffs in column $\mathrm{F}$ and their nutrient content can be changed according NRC (1994) in chemical composition page. The third sheet represents the feed requirements of the broiler and layers and the fourth sheet help explain application use. For the purpose of formulation of a ration, the cursor is placed in any of the cells in the fifth column (E) and the default values of feedstuffs ratios are added so that the total in E16 cell being 100 and can move from one cell to another in the fifth column (E) by the arrows in the keyboard where the total value for all nutrients in columns I and $\mathrm{K}$ until feed requirements are met.The purpose of this research is to create an application in the Excel spreadsheet program based on the functions, in particular the sum-product function, in which the poultry ration are calculated and configured in a trial and error method. The assumed proportions of the feed ingredients can be entered from the primary feedstuffs in column E, and once you change any of the values of the components of the diet will change the total content of diet nutrients, and so on the way to try and error can be changed components of the ration until reaching the desired goal and according to the required feed requirements and can use it to calculate the chemical composition of any ration if its components known.

\section{RESULT AND DISCUSSION}

Figure (1) shows a sample of this application where the total feedstuffs ratio should be $100 \%$ in the fifth column (E); in cell E16 it is noted from the figure that when the primary feedstuffs ratios are maize $50.25 \%$, soybeans $36.65 \%$, protein concentrate $5 \%$, sunflower oil $6 \%$, limestone $1.55 \%$, di calcium phosphate $0.25 \%$, salt $0.24 \%$, vitamins and minerals premix $0.1 \%$, anticoccidial $0.01 \%$ the total in cell E16 is 100 . Assuming that the cost of primary feedstuffs is as in the form, the cost of this feed is 904.46 dinars $/ \mathrm{kg}$. This diet provides the feed requirements of the broiler in the starter period, containing $3185 \mathrm{kcal} / \mathrm{kg}$ of ME and $22.4 \%$ of crude protein, $1.25 \%$ lysine and $0.77 \%$ methionine and Cysteine, $1 \%$ calcium and $0.33 \%$ available phosphorus and the minimum limits of other amino acids. Using 12 feedstuffs and 26 nutrients, the application needs $1 / 312(12 \times 26)$ of the time it takes to manually reach this result 
Rafh Mohamed Tahir Khalel

for each attempt. When the result is reached through 10 attempts, the application needs $1 / 3120$ of the time required for the manual method. It is noted from this that the application shortens a lot of time and effort in the formation of the diet in a trial and error method, which takes the multiplication and summation until provide of feed needs in addition to the difficulty of balancing many of the necessary nutrients.

Figure (1)

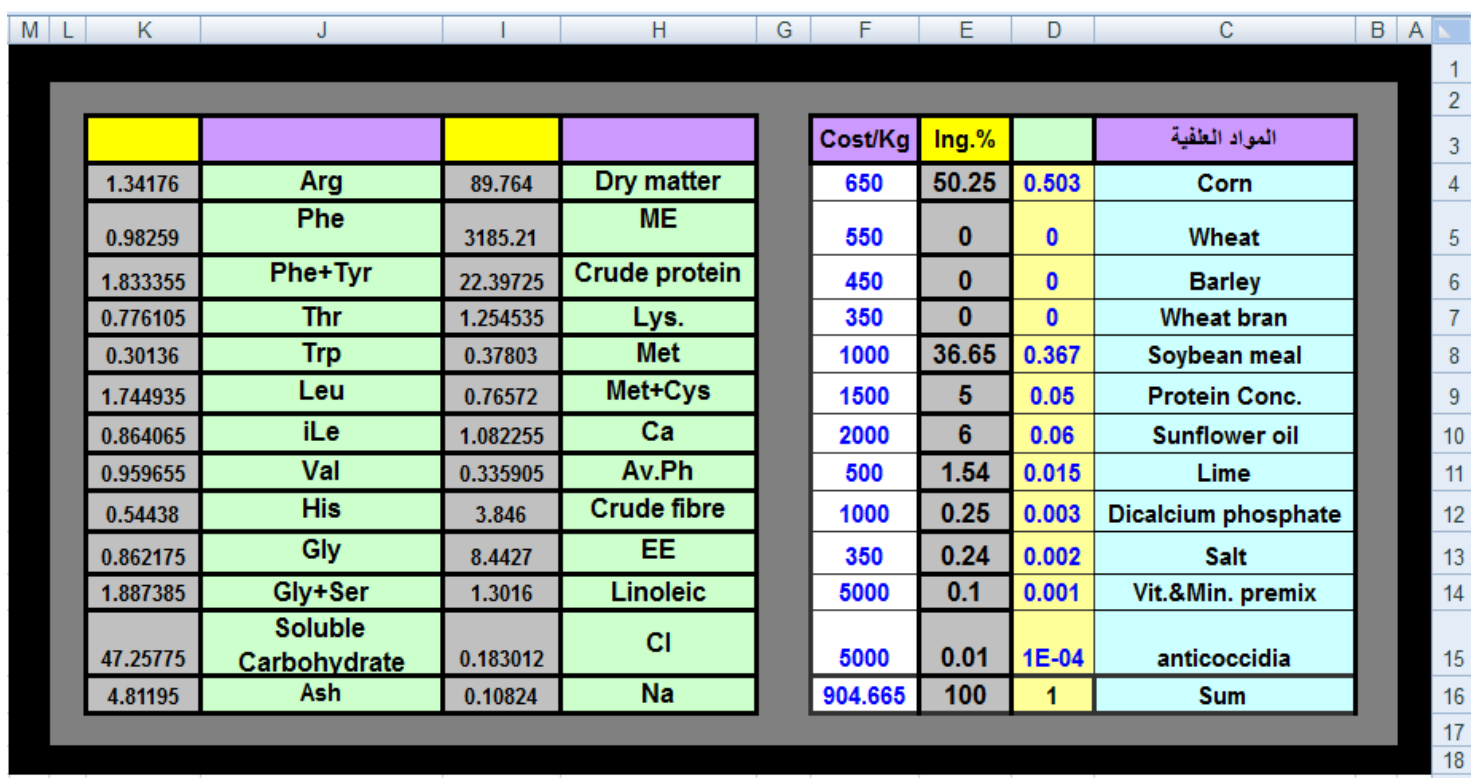

\section{REFERENCE}

Afolayan, M. O; and Afolayan, M., 2008. Nigeria Oriented Poultry Feed Formulation Software Requirements. J. Appl. Sci. Res., 4: 1596-1602.

Chakeredza, S.; Ainnifesi, F. K.; Ajay, O. C.; Sileshi, G.; Mngomba, S.; and Gondwe, F. M. T., 2008. A simple method of formulating least cost diets for small holder dairy production in sub-saharian Africa. Afr. J. Biotech., 7: 2925-2933.

NRC, National research Council, 1994. Nutrient requirement of poultry. $9^{\text {th }}$ revised edition. National Academy Press. Washington. D.C.

Pesti, G. M.; and Seila, A. F., 1999. The use of an electronic spreadsheet to solve linear and non linear stochastic feed formulation problems . J. Appl. Poult. Res., 8: 110-121.

Roush, V. B., 1994. Stochastic programming. A new generation of feed formulation. $55^{\text {th }}$ minnesota nutrition conference and Roche technical. Symposium. 19-21 Sep., 1994. Bloomington, Minnesota, USA.

Vandehaar, M. J.; and Black, J. R., 1991. Ration formulation using linear programming. Amer. J. Clinic. Nutri., 7: 541-550.

Yassin, A. A; and Abdel-Abbas, M. H., 2010. Poultry Feeding. University of Baghdad, Iraq. 


\section{الملخص العربي \\ إنشاء تطبيق في برنامج الجداول الإكترونية اكسل لتكوين علائق الدواجن بطريقة المحاولة والخطأ \\ رافع محمد طاهر خليل \\ قسم الإنتاج الحيو اني، كلية الزراعة ومثل طاهنابات جامعة الموصل، العر اق}

تهدف هذه الدر اسة إلى إنشاء تطبيق في برنامج الجداول الإلكترونية اكسل الو اسع الإنتشار وبإستخدام المو اد العلفية

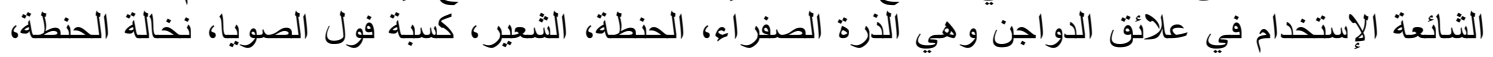

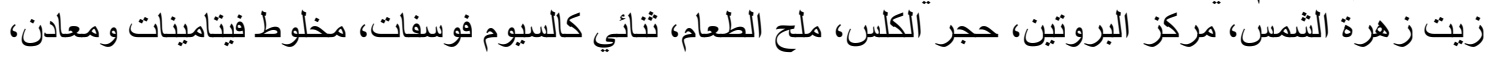

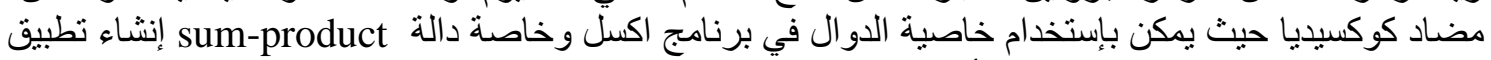

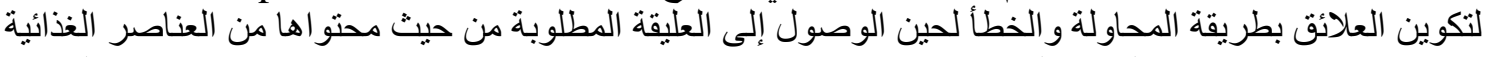

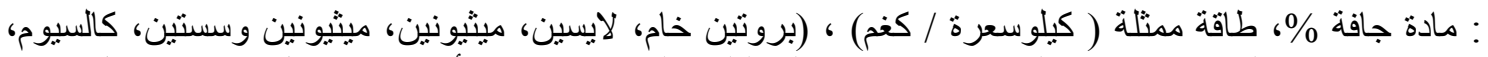

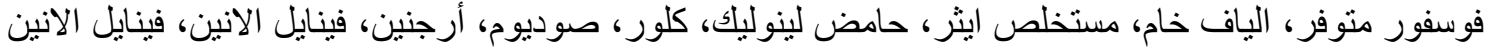

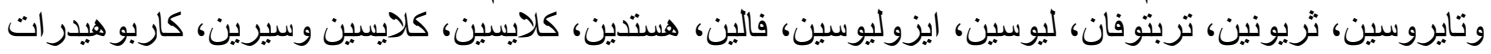

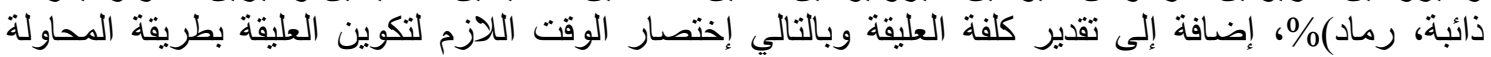
و الخطأ التقليدية والتي تستغرق الكثير من الوقت و الجهد.

كلمات مفتاحية : إنشاء تطبيق ـ اكسل ـ علائق الدواجن. 